\title{
Effects of manual therapy in the treatment of temporomandibular dysfunction - a review of the literature
}

\author{
Mirjam Evi Braun de Castro', Rodrigo Marcel Valentim da Silva', Franciane Batista Basilio²
}

\begin{abstract}
Background: The term temporomandibular dysfunction (TMD) applies to functional changes related to temporomandibular joint (TMJ) and it is associated to masticatory structures. The main symptoms are pain in the TMJ region and / or the masticatory musculature. Objective: to perform a systematic review on the effects of manual therapy in the treatment of TMD. Methods: We analyzed 231 articles from the databases of Bireme, BVS, Lilacs, MedLine, PEDro, Pubmed and, Scielo. Of these, only 30 were selected for the elaboration of the article and 6 were used for the qualitative synthesis. Studies of controlled clinical trials of high methodological quality and high clinical relevance on the PEDro scale were included, which used the same evaluation measures, VAS (visual analogic scale), PPT (pressure pain threshold) and maximum mouth opening (MMO), and only one treatment technique comparing the control group with placebo. Result: The studies presented positive results for pain in VAS, PPT and MMO; however, there are significant differences depending on the technique. Myofascial release has a strong efficacy in reducing the symptoms of acute pain in the long term, but does not show clinically significant changes in mouth opening amplitude and MMO. Mobilization / manipulation presents significant changes in MMO, significantly improving the efficacy of mouth range of motion in the treatment of the short-term pain symptom, however does not sustain in the long term. Conclusion: The tool for the individual treatment of patients is based on the symptoms addressed, significantly improving the effectiveness of the range of motion of the mouth in the treatment of joint mobilization / manipulation, and treatment of pain by myofascial release.
\end{abstract}

Keywords: Temporomandibular Joint, Manual Therapy, Myofascial Pain Syndrome, Craniomandibular, Musculoskeletal.

\section{INTRODUCTION}

The term temporomandibular dysfunction (TMD) applies to functional changes related to Temporomandibular Joint (TMJ) and it is associated to masticatory structures ${ }^{(1,2)}$. The prevalence is higher among women than in men and it is found in the age between 20 to 40 years $^{(3,4)}$. TMD is caused by hyperfunction or muscle dysfunction, traumatic lesions, hormonal influences and joint changes. The main signs identified are decreased mandibular range of motion, joint muscle pain, joint crackling, functional limitation and/or deviation of the opening of the mandible. The main symptoms are pain in the TMJ region and / or the masticatory musculature ${ }^{(3,4)}$. About $39 \%$ of the population have a sign or symptom of $\mathrm{TMD}^{(5)}$.

In the current decade, TMD treatment has an increasing multidisciplinary approach. That strategy changed the treatment for reversible and less irreversible interventions which includes psychotherapy, conventional physiotherapy, chiropractic, osteopathy, manual therapy, massage and others. This change occurred because TMD is considered a musculoskeletal condition ${ }^{(6)}$. The forms of TMD which involves the masticatory muscles are considered more common. However, TMD involving joint biomechanics, present varying degrees of myospasm or associated muscle contractures ${ }^{(7)}$.

The muscles of the masticatory system promote the dynamic stability of TMJ. They are accompanied by the cervical musculature which stabilizes and allows mandibular movement ${ }^{(8)}$. Such muscles may present myofascial trigger points (MTP's), which manifest local pain and in reference areas in the head region, muscle tension, tinnitus, torticollis and TMD. The MTP's are focal areas of strap bands in skeletal muscle which are hypersensitive to palpation and produce local pain or distal correlated areas, proportional to the applied pressure in the region ${ }^{(9,10)}$. The MTP's can be treated with noninvasive methods such as manual therapy, stretching, transcutaneous electrical stimulation and massage. Invasive

Corresponding Author: Franciane Batista Basilio. Avenida das Fronteiras, 231, Nossa Senhora da Apresentação, Natal (RN), Brazil. Cep 59114035. Phone: +55 84 988633386. E-mail: franciane.batista@hotmail.com

2 Faculdade Maurício de Nassau (FMN), Natal (RN), Brazil.

Full list of author information is available at the end of the article.

Funding: none.

Submission date 26 August 2017; Acceptance date 14 November 2017; Publication date 28 December 2017 
treatments include dry needling or injections with local anesthetics, corticosteroids or botulinum toxin. Untreated MTP's may result in a decrease in the range of motion ${ }^{(11,12)}$.

The demobilization treatment or the manipulation for TMD's generally include manipulation procedures involving TMJ or alternatively the spine and lower extremities to improve the posture and proprioception ${ }^{(13)}$. Manual therapy may include movement of the joint, mobilization or manipulation, in specific directions and at different speeds to recover movement. The selected soft tissue techniques may also be used to improve mobility and function of tissues and muscles ${ }^{(14)}$. Generally, the manual therapy improves circulation, reduces muscle spasm, relaxes muscles around the joint, realigns soft tissues, eliminates adhesions, increases range of motion, and decreases pain ${ }^{(15)}$.

The present review aims to individualize the therapeutic approaches of each technique, specifically. Because of the wide variety of techniques, the review focuses are on the most commonly used techniques. These are mobilization or manipulation of the joint and myofascial treatment in the form of MTP's.

\section{METHODS}

The present study is a review of literature, which used the Bireme, BVS, Lilacs, MEDLINE, PEDro, PubMed and Scielo databases. The period searched was 2001 to 2015 . The following search terms were used temporomandibular joint, manual therapy, myofascial pain syndromes, craniomandibular and, musculoskeletal. Articles were included in English, French, Portuguese and Spanish. The studies were considered eligible for inclusion when they were classified as controlled clinical trials, when performing a manual therapy intervention comparing to a control group and when performing manual therapy intervention with myofascial release. Studies which used more than one treatment technique were excluded from the study. Of the 231 articles initially selected by the electronic search, 30 articles were selected for the evaluation for reading the text. Finally, 6 studies were included for the synthesis of evidence after the final selection process, according to figure 1.

\section{RESULTS}

The reliability of the measurement range of the Physiotherapy Evidence Database (PEDro) was used in the present review, which is considered reasonable and valid $^{(16)}$. For the present review, six studies were selected for the synthesis of evidence. Five studies with a PEDro score between 6 and 8 were classified as studies of high methodological quality. The average score on the PEDro scale quality methodological studies was obtained by 6.67 (table 1). Only one study was classified with low methodological quality, however with high clinical relevance ${ }^{(17)}$. Only one study was not indexed by the PEDro database ${ }^{(8)}$, therefore, we evaluated its methodological quality. The average score on the PEDro scale, for the clinical relevance obtained by the studies, was 3.83 (table 1). Two studies ${ }^{(6,18)}$ achieved the highest score 5 (five) points. All others reached 4 (four) points which shows the high clinical relevance of the selected studies. Only one study ${ }^{(8)}$ showed a low clinical relevance and a high methodological quality. The least satisfactory criterion was related to the size of the importance of the clinical effect that is achieved in $50 \%$ of the studies ${ }^{(6,18,19)}$.

The characteristics of the studies are type of study, characteristics of the subjects, intervention, comparison between groups and results, which may be observed in Table 2 . The comparison between the techniques of manual therapy, magnitude of its effects and changes after the application of these techniques, are presented in Table 3.

Visual Analogic Scale (VAS) was used to record the level of patient pain at the study baseline and demonstrated to be an extremely viable and valid instrument for measuring the acute pain intensity ${ }^{(20)}$. Pressure Pain Threshold (PPT) is defined as the amount of pressure in which the pressure sensation begins to shift to pain. The use of pressure algometry may be considered a viable alternative for pain assessment.

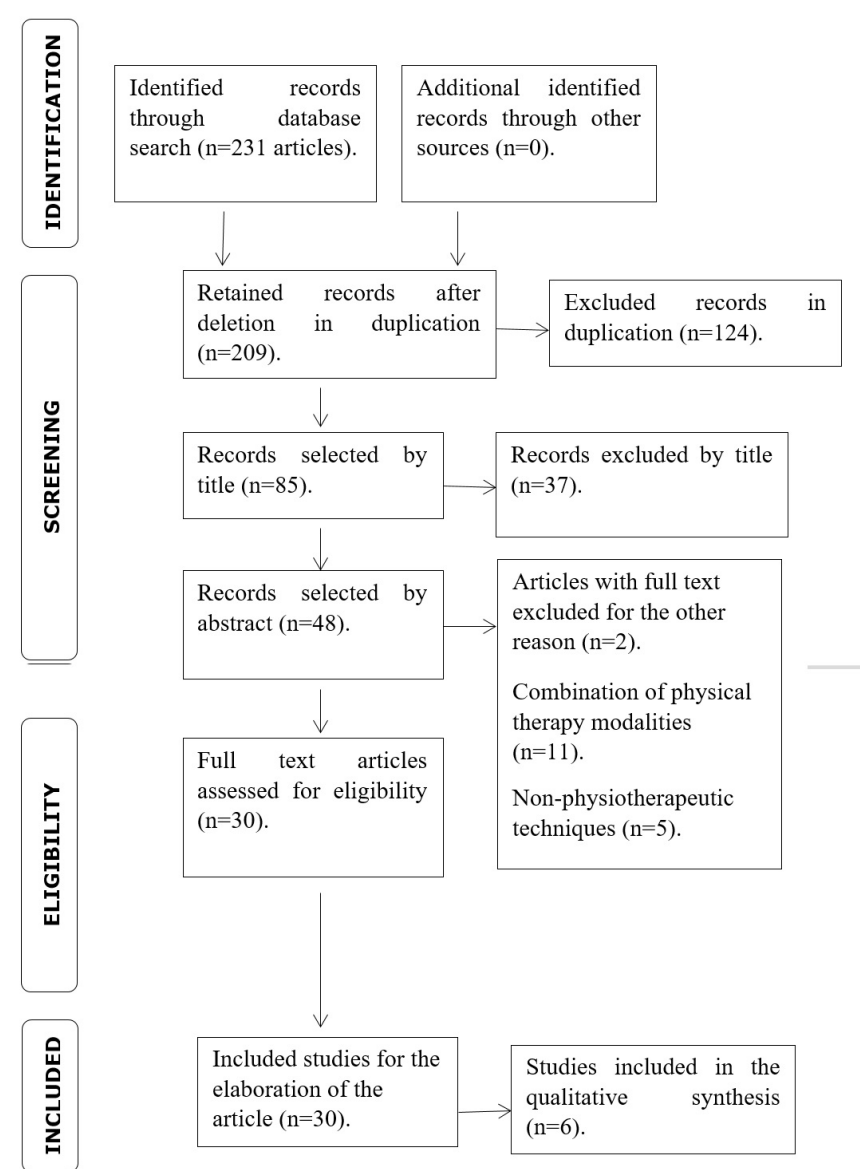

Figure 1: Search and selection of studies for review 
Table 1: Methodological quality evaluated according to PEDro scale and clinical relevance criteria

\begin{tabular}{|c|c|c|c|c|c|c|c|c|c|c|c|c|c|c|c|c|c|c|}
\hline \multirow{2}{*}{$\begin{array}{c}\text { Bias scale risk (PEDro) } \\
\text { Study }\end{array}$} & \multicolumn{18}{|c|}{ Clinical relevance } \\
\hline & 1 & 2 & 3 & 4 & 5 & 6 & 7 & 8 & 9 & 10 & 11 & $\begin{array}{l}\text { Total } \\
\text { score }\end{array}$ & 12 & 13 & 14 & 15 & 16 & $\begin{array}{l}\text { Total } \\
\text { score }\end{array}$ \\
\hline Kalami et al.; 2011. & + & + & + & + & - & - & + & + & + & + & + & 8 & + & + & + & - & + & 4 \\
\hline Kalami et al.; 2013. & + & + & + & + & - & - & + & + & - & + & + & 7 & + & + & + & + & + & 5 \\
\hline Mansilla et al.; 2008. & + & + & - & - & - & - & + & - & - & + & + & 4 & + & + & + & - & + & 4 \\
\hline LA Touche et al.; 2009. & + & - & - & - & - & - & + & + & + & + & + & 6 & + & - & - & - & - & 1 \\
\hline LA Touche et al.; 2012. & + & + & + & + & + & - & + & + & - & + & + & 8 & + & + & + & + & + & 5 \\
\hline Tuncer et al.; 2013. & + & + & + & + & + & - & + & + & - & + & + & 7 & + & - & + & + & + & 4 \\
\hline $\begin{array}{l}\text { Percentage of studies } \\
\text { meeting the criteria }\end{array}$ & 100 & 83.3 & 66.6 & 66.6 & 33.3 & 0 & 100 & 83.3 & 33.3 & 100 & 100 & $6 * .67$ & 100 & 66.6 & 83.3 & 50 & 83.3 & $3 * 8.3$ \\
\hline
\end{tabular}

Note: 1. Eligibility criteria; 2. Random allocation; 3. Hidden allocation; 4. Comparability of the baseline; 5. Blind individuals; 6. Masking patients; 7. Blind Evaluators; 8. Adequate follow-up; 9 . The intention-to-treat analysis; 10 . Comparisons between groups; 11 . Point estimates and variability; 12 . Are the patients described in detail so that you can decide if they are comparable to what you see in your practice? Are the intervention and treatment settings described well enough that you can provide the same for your patients? 14 . Were all clinically relevant outcomes measured and reported? Is the size of the effect clinically important? 16 . Are the likely benefits of treatment valid for harms? * Average score.

Table 2: Population characteristics, intervention and procedures performed in the studies.

\begin{tabular}{|c|c|c|c|c|c|c|}
\hline Author & Type of study & Subjects & Intervention & Comparation & Results & Follow-up \\
\hline $\begin{array}{l}\text { Mansilla et al; } \\
2008^{(17)} \\
\text { Risk of bias: } 4 \\
\text { Clinical relevance:4 }\end{array}$ & $\begin{array}{l}\text { Experimental, } \\
\text { controlled, single } \\
\text { blind study }\end{array}$ & $\begin{array}{l}\text { Subjects with } \\
\text { mouth opening } \\
<40 \mathrm{~mm} \text {, with } \\
\text { or without TMD } \\
\text { symptoms. } \\
\text { Headache }>1 \text { month } \\
\text { Age } 21-50 \\
\mathrm{~N}=52 \\
\text { ( } 40 \text { female and } 12 \\
\text { male) }\end{array}$ & $\begin{array}{l}1 \text { session of occipital } \\
\text { atlanto impulse } \\
\text { manipulation }\end{array}$ & $\begin{array}{l}\text { Control group and } \\
\mathrm{MMO}\end{array}$ & $\begin{array}{l}\text { MMO (calliper) } \\
\text { PPT of temporalis } \\
\text { muscles algometer. }\end{array}$ & $\begin{array}{l}\text { Immediately after } \\
\text { the intervention }\end{array}$ \\
\hline $\begin{array}{l}\text { LA Touche et al; } \\
\text { 2009(8) } \\
\text { Risk of bias: } 6 \\
\text { Clinical relevance: } 1\end{array}$ & $\begin{array}{l}\text { Randomized clinical } \\
\text { trial }\end{array}$ & $\begin{array}{l}\text { Subjects with } \\
\text { myofascial pain } \\
\text { (DRC / TMD) for } \\
\text { at least three } \\
\text { months, bilateral } \\
\text { pain presence of } \\
\text { trigger points in } \\
\text { the masseter and } \\
\text { temporal; >3 VAS } \\
\text { pain scale; } \\
\text { Age:19-57 } \\
\mathrm{N}=19 \text { (14 female } \\
\text { and } 5 \text { male) }\end{array}$ & $\begin{array}{l}2 \text { sessions per week } \\
\text { for } 5 \text { weeks. } \\
\text { Mobilization of } \\
\text { the cervical in the } \\
3 \text { upper cervical } \\
\text { segments (CO-C3). } \\
\text { The mobilization } \\
\text { was applied at a } \\
\text { rate of } 1 \text { oscillation } \\
\text { per } 2 \mathrm{~s}(0.5) \mathrm{Hz}\end{array}$ & Absent & $\begin{array}{l}\text { Pain (VAS) } \\
\text { PPT in masseter and } \\
\text { temporal ( } 2 \text { points } \\
\text { each muscular) }\end{array}$ & $\begin{array}{l}12 \text { weeks after } \\
\text { treatment }\end{array}$ \\
\hline $\begin{array}{l}\text { LA Touche et al; } \\
2012^{(18)} \\
\text { Risk of bias:8 } \\
\text { Clinical relevance:5 }\end{array}$ & $\begin{array}{l}\text { Randomized clinical } \\
\text { trial }\end{array}$ & $\begin{array}{l}\text { subjects with } \\
\text { myofascial pain } \\
\text { (RDC / TMD) for at } \\
\text { least three months, } \\
\text { bilateral pain and } \\
\text { presence of PG } \\
\text { in the masseter, } \\
\text { temporal, upper } \\
\text { trapezius and } \\
\text { suboccipital } \\
\text { muscles; > } 3 \text { on the } \\
\text { VAS pain scale; pain } \\
\text { in the neck and / or } \\
\text { shoulder; } \\
\text { Age: } 33.19 \pm 9.49 \\
n=32 \text { ( } 21 \text { female } \\
\text { and } 11 \text { male) }\end{array}$ & $\begin{array}{l}3 \text { sessions total } \\
\text { antero-posterior } \\
\text { superior cervical } \\
\text { mobilization in the } \\
3 \text { upper cervical } \\
\text { segments (CO-C3). } \\
\text { The mobilization } \\
\text { was applied at a } \\
\text { rate of } 1 \text { oscillation } \\
\text { per } 2 \mathrm{~s}(0.5) \mathrm{Hz}\end{array}$ & $\begin{array}{l}\text { Placebo technique: } \\
\text { same position of } \\
\text { the therapist's } \\
\text { hand. However, the } \\
\text { mobilization was } \\
\text { not applied to the } \\
\text { cervical spine. }\end{array}$ & $\begin{array}{l}\text { Pain (VAS) } \\
\text { PPT in masseter and } \\
\text { temporal ( } 2 \text { points } \\
\text { each muscle) }\end{array}$ & $\begin{array}{l}\text { After } 3 \text { intervention } \\
\text { sessions. }\end{array}$ \\
\hline
\end{tabular}


Table 2: Continued...

\begin{tabular}{|c|c|c|c|c|c|c|}
\hline Author & Type of study & Subjects & Intervention & Comparation & Results & Follow -up \\
\hline $\begin{array}{l}\text { Kalamir et al; } 2011^{(7)} \\
\text { Risk of bias: } 8 \\
\text { Clinical relevance: } 4\end{array}$ & $\begin{array}{l}\text { Randomized clinical } \\
\text { trial }\end{array}$ & $\begin{array}{l}\text { Subjects with } \\
\text { (RDC) / TMD) and } \\
\text { a daily history of } \\
\text { periauricular pain } \\
\text { with or without } \\
\text { joint noises } \\
\text { Age: } 18-50 \\
\mathrm{~N}=93 \text { ( } 52 \text { female } \\
\text { and } 41 \text { male) }\end{array}$ & $\begin{array}{l}2 \text { sessions per } \\
\text { week for } 5 \text { weeks. } \\
\text { Temporal intraoral, } \\
\text { medial and lateral } \\
\text { intraoral release } \\
\text { and pterygoid } \\
\text { (origin) technique. } \\
\text { Group A + } \\
\text { instructions + home } \\
\text { exercises (not } \\
\text { considered in the } \\
\text { analysis) }\end{array}$ & Control group & $\begin{array}{l}\text { MMO (calliper) } \\
\text { Resting jaw pain, } \\
\text { maximal active } \\
\text { opening (VAS) }\end{array}$ & $\begin{array}{l}\text { After five weeks of } \\
\text { intervention, six } \\
\text { months and one } \\
\text { year of follow-up. }\end{array}$ \\
\hline $\begin{array}{l}\text { Kallamir et al; } \\
2013^{(6)} \\
\text { Risk of bias: } 7 \\
\text { Clinical relevance: } 5\end{array}$ & $\begin{array}{l}\text { Randomized clinical } \\
\text { trial }\end{array}$ & $\begin{array}{l}\text { Subjects with } \\
\text { (RDC) / TMD) and } \\
\text { a daily history of } \\
\text { periauricular pain } \\
\text { with or without } \\
\text { joint noises } \\
\text { Age: } 18-50 \\
n=46\end{array}$ & $\begin{array}{l}2 \text { sessions per week } \\
\text { for } 5 \text { weeks. } \\
\text { IMT group } \\
\text { (myofascial intraoral } \\
\text { therapies). }\end{array}$ & $\begin{array}{l}2 \text { sessions for } 5 \\
\text { weeks. ESC Group } \\
\text { (Combination of } \\
\text { education and } \\
\text { home exercises) }\end{array}$ & $\begin{array}{l}\text { MMO (calliper) } \\
\text { Resting jaw pain, } \\
\text { maximal active } \\
\text { opening (VAS) }\end{array}$ & $\begin{array}{l}\text { Six weeks after } \\
\text { treatment. }\end{array}$ \\
\hline $\begin{array}{l}\text { Tuncer et al.; } \\
2013^{(19)} \\
\text { Risk of bias: } 7 \\
\text { Clinical relevance: } 4\end{array}$ & $\begin{array}{l}\text { Randomized clinical } \\
\text { trial }\end{array}$ & $\begin{array}{l}\text { Subjects with } \\
\text { myofascial pain } \\
\text { (DRC / TMD) for } \\
\text { at least three } \\
\text { months, bilateral } \\
\text { pain presence in } \\
\text { the masseter and } \\
\text { temporal. Presence } \\
\text { of a PG; with or } \\
\text { without joint noises. } \\
\text { Age: } 18-72 \\
n=40 \text { ( } 32 \text { female } \\
\text { and } 9 \text { male) }\end{array}$ & $\begin{array}{l}3 \text { sessions for } 4 \\
\text { weeks. } \\
\text { MT and HPT (intra } \\
\text { and extra oral } \\
\text { myofascial release } \\
\text { and mobilization of } \\
\text { the cervical spine } \\
\text { and instructions + } \\
\text { home exercises) }\end{array}$ & $\begin{array}{l}3 \text { sessions for } 4 \\
\text { weeks. } \\
\text { HPT (instructions + } \\
\text { home exercises) }\end{array}$ & $\begin{array}{l}\text { MMO } \\
\text { Resting jaw pain, } \\
\text { stress (chewing for } \\
60 \text { seconds) (VAS) }\end{array}$ & $\begin{array}{l}\text { After four weeks of } \\
\text { treatment }\end{array}$ \\
\hline
\end{tabular}

Table 3: Results of the studies

\begin{tabular}{|c|c|c|c|c|}
\hline \multicolumn{5}{|c|}{ Myofascial techniques in the masticatory musculature } \\
\hline Study & Manual therapy group & Comparison group & Effect magnitude & Alterations \\
\hline Kalamir et al. ; $2011^{(7)}$ & $\begin{array}{l}\text { MTI (31) } \\
\text { MTIEHE (31) }\end{array}$ & CG (31) & $\begin{array}{l}\text { MMO (mouth opening) } \\
\text { MTI, MTIEHE (p<0.001) } \\
\text { VAS (pain score)* } \\
\text { RP: MTI (3.1); MTIEHE (4.0) } \\
\text { OP: MTI (1.9); MTIEHE (4.1) } \\
\text { CP: MTI (1.7); MTIEHE (3.6) }\end{array}$ & $\begin{array}{l}\text { No change between groups } \\
\text { Changes }>2 \text { points between groups }\end{array}$ \\
\hline Kalamir et al.; 2013 $3^{(6)}$ & $\begin{array}{l}\text { MTI (23) } \\
\text { EHE }\end{array}$ & EHE (23) & $\begin{array}{l}\text { MMO (mouth opening) } \\
\text { IMT ( } p=0.032) \\
\text { EHE ( } p=0.025) ; \\
\text { VAS (decrease in pain)* } \\
\text { RP: MTI (-2.48); EHE }(-1.22) \\
\text { OP: MTI (-2.83); EHE }(-1.35) \\
\text { CP: MTI (-3.26); EHE }(-1.61) \\
\text { OR: MTI (-3.00); EHE }(-2.52)\end{array}$ & $\begin{array}{l}\text { No significant change between } \\
\text { groups } \\
\text { Changes }>2 \text { points between groups }\end{array}$ \\
\hline
\end{tabular}

Note: MTI, Manual therapy intervention group; MTIEHE, Manual therapy intervention group in combination with education and home exercises; CG, Control group; EHE, Education and home exercises group; (), number of individuals ; * six weeks after baseline; RP, resting in pain; OP, mouth opening pain ; CP, pain at closing; OR, opening range (mm); OAA, atlanto-occiptal impulse manipulation group; CM, Cervical mobilization (C0-C3); pre, before the treatment; post, after 3 treatment sessions; f.u.*, follow-up; R, right; L, left; measured with EVA. MTHPT, myofascial release intra- and extra-oral and cervical spine mobilization and instructions + exercises at home; HPT, home exercises; measured with VAS, more indicated by smaller values; ${ }^{* *}$ four weeks after baseline; SP, stress pain. 
Table 3: Continued...

\begin{tabular}{|c|c|c|c|c|}
\hline \multicolumn{5}{|c|}{ Cervical vertebral manipulation techniques } \\
\hline Study & Manual therapy group & Comparison group & Effect magnitude & Alterations \\
\hline $\begin{array}{l}\text { Mansilla et al.; } \\
2008^{(17)}\end{array}$ & OAA (26) & CG (26) & $\begin{array}{l}\text { MMO (mouth opening) } \\
\text { OAA: pre (36.0); post (39.2) } \\
\text { CG: pre (36.8); post }(36.6) \\
\text { PPT } \\
\text { OAA: pre }(0.86) \text {; post }(0.94) \\
\text { CG: pre }(0.8) ; \text { post }(0.7)\end{array}$ & $\begin{array}{l}\text { It promoted an increase } \\
\text { No significant change between } \\
\text { groups }\end{array}$ \\
\hline $\begin{array}{l}\text { LA Touche et al.; } \\
2009^{(8)}\end{array}$ & $\mathrm{CM}(19)$ & None & $\begin{array}{l}\text { MMO (mouth opening) } \\
\text { Pre: (38.3); post (42.8); f.u.* (43.1). } \\
\text { VAS } \\
\text { Pre: (55.5); post (20.9); } \\
\text { f.u.* (18.7). } \\
\text { PPT } \\
\text { Masseter } \\
\text { R: pre (2.8); post (3.9); f.u.*(3.9) } \\
\text { L: pre (2.3); post (3.6); } \\
\text { f.u.*(3,5). } \\
\text { Temporalis } \\
\text { R: pre (2.4); post (3.7); f.u.*(3.5). } \\
\text { L: pre (3.0); post (3.9); f.u.* }{ }^{*}(4.0)\end{array}$ & $\begin{array}{l}\text { It promoted an increase } \\
\text { Changes }>2 \text { points } \\
\text { It promotes a difference between } \\
\text { pre- and post-treatment, but not } \\
\text { between post and follow-up }\end{array}$ \\
\hline $\begin{array}{l}\text { LA Touche et al.; } \\
2012^{(18)}\end{array}$ & $\mathrm{CM}(16)$ & CG (16) & $\begin{array}{l}\text { PPT } \\
\text { CM }(p<0.001) \text { in CG } \\
\text { VAS (pain when opening)* } \\
\text { CM: pre }(43.88) ; \text { post }(14.75) \\
\text { CG: pre }(42.38) ; \text { post }(42)\end{array}$ & $\begin{array}{l}\text { No changes between groups } \\
\text { Changes }>2 \text { points between groups } \\
\text { (short term: three sessions in two } \\
\text { weeks) }\end{array}$ \\
\hline \multicolumn{5}{|c|}{ Combination of myofascial treatment in the masticatory musculature and cervical vertebral and ATM mobilization techniques } \\
\hline Study & Manual therapy group & Comparison group & Effect magnitude & Alterations \\
\hline Tuncer et al.; $2013^{(19)}$ & MTHPT (20) & HPT (20) & $\begin{array}{l}\text { MMO (mouth opening) } \\
\text { MTHPT: pre (38.6); post (44.4) } \\
\text { HPT: pre (39.0); post (41.4) } \\
\text { VAS (decrease in\%) ** } \\
\text { RP: MTHPT: } 59,2 \% \\
\text { HPT: } 34,6 \% \\
\text { SP: MTHPT: } 91,3 \% \\
\text { HPT: } 35,7 \%\end{array}$ & $\begin{array}{l}\text { Changes }>2 \text { points between groups } \\
\text { Alterations between resting and } \\
\text { stress groups }\end{array}$ \\
\hline
\end{tabular}

Note: MTI, Manual therapy intervention group; MTIEHE, Manual therapy intervention group in combination with education and home exercises; CG, Control group; EHE, Education and home exercises group; (), number of individuals ; ${ }^{*}$ six weeks after baseline; RP, resting in pain; OP, mouth opening pain ; $C P$, pain at closing; OR, opening range (mm); OAA, atlanto-occiptal impulse manipulation group; $\mathrm{CM}$, Cervical mobilization (CO-C3); pre, before the treatment; post, after 3 treatment sessions; f.u. ${ }^{*}$, follow-up; R, right; L, left; measured with EVA. MTHPT, myofascial release intra- and extra-oral and cervical spine mobilization and instructions + exercises at home; HPT, home exercises; measured with VAS, more indicated by smaller values; ${ }^{* *}$ four weeks after baseline; SP, stress pain.

(ICC $=0.91[95 \% \text { confidence interval }(\mathrm{Cl}) \text { : from } 0.82-0.97]^{(21)}$. The active maximum mouth opening without pain (MMO) is evaluated at dorsal decubitus. The subjects are requested to open their mouth as much as possible without pain. At this maximum position, the distance between the upper and lower central incisors is measured in $\mathrm{mm}^{(22)}$. The GRC are used to guide TMD researchers who advocate their inclusion in the conclusions on therapeutic pathways ${ }^{(7,23)}$. Several studies have investigated the validity of GRC scales ${ }^{(7,24)}$.

\section{DISCUSSION}

The results show that the treatment of myofascial release has a strong efficacy in decreasing the acute pain symptoms in a long term. However, it does not show clinically significant changes in the extent of mouth opening and MMO. However, the mobilization and/or manipulation of the cervical region present significant alterations in the range of mouth opening. These techniques also present a decrease in the pain symptom. The significant difference is that mobilization may only sustain that pain relief effect in short-term. In the long term, this technique may not sustain the same effect when the punctual pressure is applied.

Many studies report that the therapy of mobilization and/or manipulation of the spine cervical for a TMD treatment, may cause an correspondence and a biomechanical relationship between the TMJ system and the cervical spine. The movements of the atlanto-occipital joint, particularly the C1-C3 cervical vertebrae, occur concomitantly with 
the activation of the masticatory muscles and the proper positioning of the mandible. Therefore, changes of the cervical joints influence the biomechanics of the TMJ, affecting the proper function of the mandible, which ends in a decreased mouth opening ${ }^{(25-27)}$. Generally, joint mobilization techniques are applied in an attempt to reduce pain and increase mobility of the cervical joint, resulting in an increased mandibular mobility, which result in an increase in the range of the mouth opening $^{(26)}$.

When a muscle presents MTP's, the local mechanical balance worsens. Besides that, if a pain caused by a MTP is not treated for a significant period, or is constantly activated (as in the case of chewing), an imbalance is created in the muscle, which leads to a joint dysfunction, in this case $T D^{(28)}$. Other studies points out several theories related to the occurrence of PMG's such as the failure of the motor plate function. The motor plate dysfunction caused by MTP's and activation of several sensory and motor receptors. The sensitive mark is a pain receptor and a site for sensitizing nerve endings along the muscle. This implies that MTP's are associated with autonomic nervous irritation ${ }^{(28,29)}$ which causes pain and needs to be treated separately.

Theories regarding the central nervous system address a central spinal tenderness and/or irritation. In particular of motor cells, which occurs because of a chronic MTP. When there are active MTP's, a constant nociceptive stimulation appears in the dorsal horn of the spinal segment, increasing the muscle tone and causing mechanical imbalance of the chronic musculature. It should be added that manipulation techniques may correct a misalignment in the position of the spine and prevent the formation of MTPs, however mobilization may not treat the MTP and, consequently, pain ${ }^{(28,30)}$.

\section{CONCLUSION}

From the review of the studies, we conclude that physiotherapists may be offered a tool for the individual treatment of patients based on the symptoms, allowing significant improvement and efficacy of the range of motion of the mouth in the treatment of joint mobilization and/or manipulation. This technique should be undertaken as a first choice by the professional for the improvement of joint mobility. In case of pain should only be applied in the short term. The main approach to treating pain should be myofascial release. This technique shows a short- and long-term pain release. There are currently no studies comparing these two techniques of manual therapy, mobilization and/or cervical manipulation, and myofascial release directly. The present study provides a basis for future clinical studies.

\section{AUTHOR'S CONTRIBUTION}

MEBC was the author of the study. RMVS contributed to the design, study design and critical review of content. FBB contributed to the design and writing of the manuscript.

\section{CONFLICTS OF INTEREST}

None

\section{AUTHOR DETAILS}

1 Universidade Federal do Rio Grande do Norte (UFRN), Natal (RN), Brazil.

\section{REFERENCES}

1. Kinote APBM, Monteiro LT, Vieira AAC, Ferreira NMN, Abdon APV. Perfil funcional de pacientes com disfunção temperomandibular em tratamento fisioterápico. Rev BrasPromoç Saúde. 2011;24(4):306-12.

2. Dym $\mathrm{H}$, Israel $\mathrm{H}$. Diagnosis and treatment of temperomandibular disorders. Dental Clinics. 2012;56(1):149-61.

3. Liu F, Steinkeller A. Epidemiology, Diagnosis, and Treatment of Temporomandibular Disorders. Dent Clin North AM. 2013;57(3):465-79.

4. Calixtre LLB, Moreira RFC, Franchini GH, Alburquerque-Sedin F, OLIVEIRA $A B$. Manual therapy for the management of pain and limited range of motion in subjects with signs and symptoms of temperomandibular disorder: a systematic review of randomized controlled trails. Journal of Oral Rehabilitation. 2015;42:847-61.

5. Gonçalves DADG, Dal Fabro AL, Campos JADB, Bigal ME, Speciali JG. Symptoms of temporomandibular disorders in the population: an epidemiological study. J Orofac Pain. 2010;24:270-8.

6. Kalamir A, Graham PL, Vitiello AL, Bonello R, Pollard H. Inter-oral myofascial therapy versus education and self-care in the treatment of chronic, myogenous temporomandibular disorder: a randomized, clinical trail. Chiropractic Manual therapies. 2013;21(17).

7. Kalamir A, Bonello R, Graham P, Vitiello AL, Pollard H. Intraoral myofascial therapy of croniomyogenous temporomandibular disorder: a randomized controlled trail. Journal Manipulative Physiol. Therapy. 2011;35:26-37.

8. La Touche R, Fernandez-De-Las-Peñas C, Fernández-Carnero J, Escalante K, Ângulo-Díaz-Parreño S, Paris-Alemany A. The effects of manual therapy and exercise directed at the cervical spine on pain and pressure sensitivity in patients with myofascial temporomandibular disorders. Journalof Oral Rehabilitation. 2009;36:644-52.

9. De Freitas DG, Pinheiro IOC, Vantin K, Meinrath NCM, de Carvalho NAA. Os efeitos da desativação dos pontos- gatilho miofasciais, da mobilização articular e do exercício de estabilização cervical em uma paciente com disfunção temperomandibular: um estudo de caso. Fisioter. Mov. 2011;24(1):33-8.

10. Borg-Stein J, laccarino MA. Miofascial Syndrome treatment. Phys Med Rehabil Clin. 2014;25:357-74.

11. Graff-Radford SB, Bassiur JP. Temporomandibular disorders and Headaches Neurol Clin. 2014;32:525-37.

12. Özkan F, Çakir Özkan N, Erkorkmaz Ü. Trigger point injection therapy in the management of myofascial temporomandibular pain. Ağri Clinical Trials - Klinik Çalişma. 2011;23(3):119-25.

13. Kalamir A, Pollard H, Vitello AL, Bonello R. Manual therapy for temporomandibular disorders: A review of literature. Journal of Bodywork and Movement Therapies. 2007; 11(1):84-90.

14. American Physical Therapy Association (APTA). Manipulation education manual for physical therapist professional degree programs manipulation. Available at: http://www.Apta.org/uploadedFiles/ APTAorg/Educators/Curriculum_Resources/APTA/Manipulation/ ManipulationEducationManual.pdf; [Accessed 13 Apr 2016].

15. Bialosky JE, Bishop MD, Price DD, Robinson ME, George SZ. The mechanisms of manual therapy in the treatment of musculoskeletal pain: a comprehensive model. Man Ther. 2009;14:531-8.

16. De Morton NA, The Pedro scale is a valid measure of the methodological quality of clinical trials: a demographic study. Australian Journal of Physiotherapy. 2009; 55(2):129-33.

17. Mansilla FP, Boscá GJJ. Efecto de la manipulación de la charnelaoccipitoatlo- axoidea em la apertura de la boca. Osteopatía Científica. 2008;45-51. 
18. La Touche R, Paris-Alemany A, Mannheimer JS, Ângulo-Díaz-Parreño $\mathrm{S}$, Bishop MD, Lopéz-Valverde-Centeno A, Von Piekartz $\mathrm{H}$, FernándezCarnero J. Does mobilization of the upper cervical spine affect pain sensitivity and autonomic nervous system function in patients with cervico-craniofacial pain? A randomized-controlled trail. Clin J Pain. 2012;29(3):205-15

19. Tuncer $A B$, Ergun $N$, Tuncer $A H$, Karahan S. Effectiveness of manual therapy and home physical therapy in patients with temporomandibular disorders: a randomized controlled trail. Journal of Bodywork and Movement Therapies. 2013;17:302-08.

20. Bijur P, Silveer W, Gallagher JE. Reliability of the visual analogue scale for measurement of acute pain. Acad Emerg Med. 2001;8:1153-7.

21. Chesterson LS, Sim J, Wright CC, Foster NE. Inter-rater reliability of algometry in measuring pressure pain thresholds in healthy humans, using multiple raters. Clin J Pain. 2007;23:760-6.

22. Goulet JP, Clark GT, Flack VF, Liu C. The reproducibility of muscle and joint tenderness detection methods and maximum mandibular movement measurement for the temporomandibular system. Orofac Pain. 1998;17-26.

23. Haythornthwaite JA. Impact recommendations for clinical trails: opportunities for the RDC/TMD. J Oral Rehabil. 2010;37:799-806.
24. Kamper SJ, Maher CG, Mackay G. Global rating of change scales: a review of strengths and weaknesses and considerations for design. J Man Manip Ther. 2009;17:163-70.

25. Kamoneski $\mathrm{DH}$, Fonseca $\mathrm{CL}$, De Souza TP, Zamunér $\mathrm{AR}$, De Oliveira Peixoto B, Yi LC. Efeito imediato da manipulação Thrust aplicada na coluna cervical alta sobre a abertura ativa da boca: ensaio clínico randomizado. J Health Sci Inst. 2012;30(3):277-80.

26. Peroni CR, Oliveira AS, Bézin F. Immediate effect of cervical mobilization in temporomandibular disorder patients. Braz J Oral Sci. 2005;4(15):911-8.

27. Catanzariti JF, Debuse T, Duquesnoy B. Cervicalgies Chroniques Et Dysfonctionnement de láppareilmanducateur. Revue du Rhumatisme. 2005;72:1283- 7 .

28. Xiaoqiang Z, Shusheng T, Qiangmin H. Understanding of myofascial trigger points. Chinese Medical Journal. 2014;127(24).

29. Lv J, Huang QM, Tang L. The Studies of electrophysiology and histopathology of chronic model of myofascial trigger points in rat. Chin j Sports Med. 2013;32:621-8.

30. Mense S. How do muscle lesions such as latent and active trigger points influence central nociceptive neurons? J Musculoskelet Pain. 2010;18:348-53. 